\title{
POTENTIAL EFFECTS OF TURKEY'S MEMBERSHIP IN THE EC ON ISRAEL'S ECONOMY*
}

\author{
Alfred TOVIAS and Eyal INBAR**
}

\section{INTRODUCTION}

The purpose of our paper is to evaluate the economic and political effects of a possible accession of Turkey into the EC on Israel. The main objective of the European Community nowadays is completing its internal market by the end of 1992 and preparing the ground for monetary union towards the end of this decade. In spite of the EC's desire not to be distracted with other agendas, several countries have already asked for accession (Turkey, Malta, Cyprus, Sweden and Austria) and some other EFTA countries intend to do so. Given the economic and political importance of some of the new candidates, the EC will not be able to postpone discussion of the enlargement issue and will have to take all these requests into consideration in the near future.

Turkey's membership into the EC requires a prior solution to several economic and political issues, at least according to the Community. The basic problem is the tense relations between Turkey and Greece over the Cyprus dispute. Greece can block Turkey's accession to the Community and a solution to the conflict is not in sight, at least in the short run.

The accession of Sweden and Austria is likely to be smoother and faster. Actually, there is some talk that the Commission will start negotiations, at least regarding Sweden, already in 1992, a year earlier than expected ${ }^{1}$.

Nevertheless, our paper focuses on the possibility of a future southern enlargement of the EC, for at least two reasons: Turkey is probably the most important nonmember Mediterranean country for the EC, both economically and politically. Second, its entry into the Community may have more implications on Israel than the accession of Central or Northern European countries.

- Paper presented at the International Workshop organized by the Friedrich Naumann Foundation on November 28, 30, 1991, Antalya, Turkey on "Actual Situation and Prospects of Turkey's Bilateral Relations with Israel"

** Professors in the Hebrew University, Israel .

1 The Jerusalem Post, October 23, 1991 
The relations between Turkey and the EC have suffered from sharp fluctuations, thus affecting inevitably the level of cooperation between both partners. It is difficult to discern a trend in those relations. The non fulfillment by both sides and at different periods of what had been agreed explains also the prolongation of the time schedules which were foreseen in the different agreements concluded, although as we will see, more recently the two parties have been trying to catch up at least partially the time previously lost.

This is not the place to review the history of Turkey-EC relations. Suffice it to say that the 1963 Association Agreement contemplated the creation of a Customs Union as well as a Common Market for production factors (the four freedoms) after a preparatory period of at least five years, after which and upon a decision of the Association Council, the parties would initiate a transitory period of at most 12 years (with some exceptions). The idea was that in practice Turkey would be part of the Common Market (not necessarily of the EC) by the mid-1980s. This timing was not respected. In February 1990, however, and as a result of some improvement in EC-Turkey relations since the mid 1980s, the European Council adopted a recommendation by the Commission to establish the Customs Union by 1995. In spite of other precedents, we have assumed for the purposes of this research that this time the schedule will be respected. Observe that all this does not necessarily mean that Turkey will be accepted as a full member of the EC later on, but there are several factors that the Community will have to take into consideration should it decide to reject EC membership for Turkey upon completion of the Customs Union in the mid -1990s.

First, at that time the applications for accession of rich and developed countries like Sweden and Austria will have already been considered by the EC. Maybe these last two countries will already be EC members, thus strengthening the industrial basis of the EC and the power of Northern countries in it. The extent of restructuring and adjustment aid to these countries will be far smaller than the aid which would have to be allocated to East European countries and Turkey in order to bring their economies to the Community level. If so, and provided that Turkey continues its fast economic development, it is likely that the objection to membership will lessen. More generally, it may not be easy for the Community to enlarge further the EC without accepting Turkey as well. The EC will not be able to ignore the fact that Turkey is a growing export market for her, a place to invest and also a bridge to the Middle East for all kinds of purposes. 
Second, Community's decision makers and member states will have to take into consideration as well Turkey's constant rapprochement to the West, emphasized during the Gulf crisis of 1990-1991.During that period, Turkey chose very bravely to align itself on the international community positions led by theU.S. and to strictly adhere to the decisions of the Security Council of the U.N., even under Iraqi threats. Turkey closed the Iraqi pipelines, deployed its army along its borders with Iraq and even permitted the US Air Force to use Turkish airfields to launch attacks on Iraq. This courageous stand proved Turkey's solidarity with international efforts to overcome nacked agression by a fellow Islamic country. ${ }^{2}$ Turkish adherence to the decisions of the U.N. caused to its economy economic damage evaluated in billions \$. Not surprisingly, then, Turkey expects Western Europe's gratitude to materialize in three ways. One is compensating for war dammages ${ }^{3}$ and another is raising European quotas on a series of restricted exports. However, the most important request to the the EC is accepting future membership in the future ${ }^{4}$.

Third, Turkish cooperation for achieving stability in the Middle East is very important to the EC. A conference concerning water problems of the Middle East is to be held early next year in Turkey and there is also a Turkish proposal to institutionalize economic cooperation between the countries of the region in order to strengthen any peace settlement there. President Ozal has also declared that his country is willing to take part in efforts to solve the Israeli-Arab dispute 5 .

Fourth, the Community seems interested to assist Turkey in maintaining current economic growth in order to stem Turkish migration to the EC, specially at a time when thousands of workers from Eastern Europe and from the Maghreb are moving to the Community countries because of lack of growth there. The EC fears such a trend caused by the instability in much of its periphery, and surely must be willing to assist Turkey to avoid in its efforts to develop exports of goods and services rather than exporting workers.

2 To be sure, Turkey was not the only Islamic state joining forces against Iraq.

3 The EC has already assisted Turkey with $\$ 250$ million.

4 Turkey cannot easily sollicit a write-off or a reduction of its debts the way Egypt did with the U.S. since the majority of its loans were contracted with private banks.

5 Globes (Israel), March 261991.

6 Kramer. H. (1988), Westeuropa und dle Turkel: auf dem Weg zum 13. Mitglied der EG?, Ebenhausen, Stiftung Wissenschaft und Politik, p. 391. 
Fifth, according to Kramer ${ }^{6}$, since the 1980's Turkey considers itself to be the "Japan" in the region planning to establish close economic cooperation both with Middle Eastern countries but also along the shores of the Black Sea with the U.S.S.R., Romania and Bulgaria. These plans are becoming more realistic after the virtual disintegration of the U.S.S.R. into republics, all but one (i.e., Russia) much smaller than Turkey in economic and demographic terms. While in starategic terms, Turkey's importance to Europe has somewhat diminished as a result of the end of the Cold War, the contrary is the truth in economic and in geopolitic terms.

Sixth, the Community may seek to solve the dispute over Cyprus in the same way the creation of the ECSC solved the problem of Franco-German relations after 1945. It may ask Turkey to join the Community and by doing so create a mechanism for achieving a solution to that issue.

While we cannot ignore the fact that the Motherland Party, whose policies have contributed a great deal to the Turkish rapprochement to the West and to economic development, has had a setback in the recent elections, we are positive and therefore we assume in what follows that the new government will keep the same path in achieving economic development and strengthening ties with the EC.

\section{A PRIORI IMPACT OF INSTITUTIONAL CHANGES AFFECTING FUTURE TURKISH-EC RELATIONS}

\section{A. CURRENT ISRAELI-EC INSTITUTIONAL LINKS;}

The economic relations between Israel and the EC are based mainly on the Free Trade Area agreement which was signed in 1975. Bilateral free trade was achieved by 1989 . This agreement includes industrial products (except a large number of processed agricultural products). Israel and the EC also signed at the time a preferential agreement for agricultural products, involving larger tariff reductions on Israeli exports to the Community than on European export to Israel. In fact, more than $70 \%$ of Israeli agricultural exports to the EC benefitted from a reduction of more than 50\% of the CCT. As for the rest of its agricultural export, Israel enjoyed the MFN status according to the GATT. As a result of Spain's entry into the EC and in order to minimize trade diversion away from Israel, an additional protocol between Israel and the EC was concluded and ultimately ratified by the European Parlia- 
ment in October 1988, whereby products listed in annexes (certain vegetables, fruits and flowers) originating in Israel would be subject at any time to the same tariffs as those levied on imports from Spain although this would be, with a few exceptions, only applicable to quantities deemed to represent the average volume of past Israeli exports to the EC. Tariffs will be progressively reduced until full removal by January 1, 1996, Moreover in the protocol the EC pledged to examine the possibility lowering minimum entry prices for citrus fruit starting in 1990, the date when Spain began to enjoy all the benefits procured by the GAP to the fruit and vegetable sectors ${ }^{7}$. More recently, in the spring 1991, in the wake of the Gulf crisis, the EC has announced its intention to deepen its relations with Israel to bring them to the level of those with EFTA countries. More concretely, different newspapers announced that the EC could accept in time Israel's entry in the European Economic Area against participation by the EC in the Middle East Peace talks ${ }^{8}$.

Politically, the relations between Israel and the Community are institutionalized by an exchange of ambassadors, reciprocal visits by parliamentary delegations and yearly meetings of the Cooperation council contemplated in the different agreements. The main obstacle to better relations is the IsraeliPalestinian issue. The Community's position towards that issue was clearly expressed in the Venice declaration of 1980, which called for recognition of the rights of the Palestinian people for self-determination, a stand which is opposed to the views of the present government of Israel. The Community is also sensitive to the distress of Palestinians in the territories administered by Israel since 1967 and supports them with financial and other forms of aid. It also insists on the principle that Palestinian products to the EC should be directly exported to the Community and benefit from the same regime as Israeli exports do.

\section{B. TURKISH-EC INSTITUTIONAL LINKS:}

The relations between Turkey and the EC are based on several agreements which were signed in the 1960's and the 1970's, and on additional understandings between them as of the middle of the 1980's.

7 Financial and technical cooperation is of lesser imoprtance when compared both to institutionalized trade cooperation and to what order Mediterranean non member countries get in this respect from the EC.

8 Jerusalem Post, June 61991. 
The first agreement was an Association agreement which was signed in Ankara in 1963. The purpose of that agreement was to assist Turkey in improving its economy, its level of employment and its standard of living. It was also agreed that for a later stage (the so-called transitory stage) the two contracting parties would establish a customs union between them, coordinate their economic policies and move towards a gradual liberalization in the fields of services, movement of workers and the right of establishment. The two parties agreed that upon the completion of all the above, the Community would consider the possibility of a Turkish accession to the EC.

The agreement procured Turkey with unilateral concessions by the EC benefitting its agricultural exports.(The four main export products-raisins, dried figs, tobacco and nuts were subjected only to quotas). The Community also loaned 175 million UA, in order to assist Turkey in adapting its market to the one of the Community and to soften the shock of opening partially its domestic market to EC exports. At that time this assistance was in relative terms substantial, taking into account that Turkish exports to the EC were less than $\$ 500$ million.

In 1973 an "additional protocol" signed in 1970 came into force. It was supposed to complete the customs union by 1995 and it also procured Turkey further concessions in exports to the EC, including duty-free export of industrial products (except textiles and certain petroleum products which were subjected only to quotas that were supposed to be abolished after twelve years). Turkey also received further concessions on EC agricultural imports, so that $90 \%$ of Turkish exports to the EC would from then on enjoy various levels of concession. In the same year, after the accession of Great Britain, Ireland and Denmark to the EC, the quotas on Turkish exports of textile and the petroleum products were raised. Turkey undertook to abolish all tariffs on imports from the Community within 22 years, to adopt the CCT during that period, to liberalize the imports from the Community and to gradually adopt the CAP.

After 1974 there was a serious setback in Turkish-EC relations in the wake of the economic slowdown which happened after the oil crisis of 1973 , the Turkish invasion of Cyprus and the military takeover of 1980. Community aid to Turkey was suspended and both Turkey and the EC imposed trade limitations on their bilateral trade for economic (i.e., not political) reasons. As a result, Turkey retaliated and suspended the scaled reduction of its own tariffs. The time schedules agreed upon in the agreements of 1963 and 1973 
became irrelevant after 1975.9

From 1983 on, the mutual relations improved. Turkey submitted its formal application to join the EC on April 1987. The application was discussed in the European Parliament, the Commission and the Council of Ministers but Turkey did not receive an encouraging answer. Nevertheless, on February 1990 the Council of Ministers announced the strenghening of the cooperation between the EC and Turkey, upon the recommendation of the Commission, including ${ }^{10}$ :

1. The establishment of a customs union by the end of 1995 (in fact as originally scheduled in the 1970 protocol).

2. The promotion of cooperation in the areas of industry, technology, services, transportation, energy, telecommunication and environment.

3. The renewal of financial cooperation-loans and grants of 600 million ECU, which had to be disbursed much sooner. This was the second financial protocol. If everything had gone according to schedule we could be by now in the fourth protocol.

4. The promotion of the political cooperation by opening a dialogue between the two parties.

Summing up, the Community grants Turkey at present substantial trade concessions to its exports to Europe. Most industrial exports enjoy duty-free access to the Community's market, although exports of textile and petroleum products are limited by quotas. In addition, almost all agricultural exports to the Community benefit from some kind of preference, although Turkish exports fall under strict CAP rules concerning non-members imports (e.g. variable levies).

On the other hand, EC exports to Turkey are not barrier-free neither. They are limited by quotas, import licences and also various taxes (preferential customs duties, Housing fund tax), although, compared to the past, the attitude towards imports from the EC and from elsewhere for the matter is much more liberal. As a result of the decisions of February 1990, Turkey is

9 For Israel, the fact that provisions on the free labor movement between Turkey and the EC were not applied, as scheduled, in December 1986 is of no direct concern.

10 Europe, Documents, No. 1589. December 20 1989. For the record, let us remind here that Turkey and EFTA have recently signed a FTA agreement which must be ratified before January 1 1992. Israel and EFTA are also negotiating such an agreement right now. 
catching up, by reducing rapidly tariffs on EC exports.

Politically, there is a constant exchange of delegations, day to day contacts of officials of both sides and also meetings of a joint parliamentary committee. Turkey and the Community have the same stand towards the Israeli-Arab conflict and both parties share the belief that the Palestinians deserve self-determination.

What about the a priori impact of these current links on Israel? Israel's trade with the EC is not much affected by Turkish-EC links, specially regarding industrial exports to the EC. The free trade area for industrial products between Israel and the EC allows Israel to export almost with no limitations; therefore concessions given by the EC to Turkey do not affect the ability of Israeli industrialists to access the Community's market. This does not mean that there is no overlapping of Israel's and Turkey's exports to the EC (see later), but this is part of the normal competitive game. If something, Israel benefis currently from the fact that Turkish textile exports to the EC are restricted. On the other hand, Israeli exporters are increasingly discriminated in the Turkish market as a result of Turkey's tariff dismantling vis-a-vis the EC and now EFTA. While for the moment the impact may be limited because it takes one to three years for (Community and EFTA) operators to exploit the new opportunities, this may change by 1994-95, even before the completion of the EC-Turkey Customs Union.

In the agricultural domain, Turkey has had an advantage over Israeli exports to the EC, because Turkey's main export products are limited only by quotas, while (reduced) duties on Israeli-originating imports still prevail. As explained above, this will change by 1996 . Nevertheless, and more practically, overlapping agricultural exports (see later) is limited to a few products (such as grapes and tomatoes).

In the political realm, EC-Turkish relations do not have any significant meaning for Israel.

\section{TURKISH LINKS AFTER THE CREATION OF THE CUSTOMS UNION IN 1995:}

The customs union between the EC and Turkey will, no doubt, develop further their mutual trade links. On top of the free trade area between them, Turkey will adopt the CCT, lower its import taxes on EC exports and adjust itself to the Common Commercial Policy applied by the EC on third coun- 
tries (including Israel).

The new situation will open the EC's market to Turkish exports (including textiles and clothing). On the Turkish side, the adoption of the acquis communautaire means not only opening its domestic industrial market to EC countries but also to EFTA, ACP and Mediterranean-non member countries, including Israel. It is likely that present limitations on agricultural exports from Turkey to the EC will not be entirely abolished at this stage because of sensitivity of some member states.

All this is not supposed to challenge Israel's free trade area with the EC, but there will be some trade diversion in textiles and clothing (see later). Turkey actually will adopt the 1975 agreement by signing a protocol of adaptation (as in the case of Spain, Greece and Portugal). Its economic impact is analysed below. Politically, nothing will change for Israel, because Turkey will not be part of any institution of the Community or be a member of EPC.

\section{TURKISH ACCESSION TO THE COMMUNITY (THE TRANSI- TION PERIOD):}

It is not easy to estimate the probable length to the transition period towards full Turkish integration into the EC. On the other hand, considering the fact that the transition period in the cases of Great Britain, Ireland and Denmark was five years, of Greece seven years and of Spain and Portugal ten years, one may estimate a probable transition period of at least ten years for Turkey and this once entry is approved. But on the other hand, it may be much less, say 5 years, given that by 1996 the starting position will be the one of a Customs Union, a stage much beyond, say, than the Preferential Agreement prevailing between Spain and the EC until 1986, when the former entered the Community.

Note that the official entry date of Turkey into the EC will not substantially change its trade relations with the Community. Under the Customs Union agreement, Turkey already will benefit from free trade with the EC. However, it is likely that at entry and during (most of) the transitory period, limitations on Turkish agricultural exports will not (yet) be abolished, for two reasons. First, to avoid as long as possible adjustment by competing Community farmers, especially in Greece as well as in other Southern European countries. Second, to avoid giving an immediate advantage to Turkish products over agricultural exports from countries which already enjoy Com- 
munity preferences (such as Maghreb countries, but Israel as well). It is also likely that Turkish workers will not benefit yet from free access to Community labour markets at the entry date.

On the other hand, the accession will be very important for Turkey in some other domains. First, Turkey will become a member with full rights in EC institutions and will take part in the decision-making process of the Community. Since the criteria used to fix the number of delegates per country in each institution are based partly on size of population, the Turkish weight in the institutions is likely to be greater than the Irish, Greek or Belgian ones. Second, the less developed areas in Turkey will enjoy the Community's aid from EC structural funds (such as the ERDF), and loans from the EIB. Third, Turkey will adopt the CAP. That means that Turkish farmers will get export assistance and guaranteed prices. It also means that Turkey will have to adhere strictly to EC quality and health standards. Fourth, Turkey will become a full partner of all the common policies of the EC (such as fisheries policies).

Turkish membership in the EC will have some important economic and political implications for Israel. For instance, a large share of Community's budgetary funds will be directed to Turkey, something which may leave less for external aid. Israel is not considered to be a developing country any more and might get an even lower priority than now in the Community's aid allocation. On the other hand, the participation of Turkey in EC institutions may heighten the awareness of the EC with respect to links with the Middle East and the Eastern Mediterranean (the former Ottoman empire), a little in the same way as the presence of Spain in the Community has led to better EC relations with Latin America. The EC will include an important member fighting for stability and economic prosperity in the Middle East, something which should benefit Israel.

By the time of accession, Turkey will be expected to have diplomatic relations at the highest level with all the countries in the Middle East and the Eastern Mediterranean, including Israel. Of course, this could happen well before accession ${ }^{11}$.

11 According to Yediot Aharonot November 21 1991, Turkey will establish full diplomatic relations with Israel in the coming months. 


\section{E. SITUATION AFTER THE END OF THE TRANSITORY PERIOD ONCE TURKEY IS AN EC MEMBER.}

At that stage, Turkey would have an advantage over Israel in exporting its agricultural products to the Community. Israel may ask for compensations (as it did in the case of Spain and Portugal) but it is not clear yet whether the EC would accede. However, by the time the transitory period would finish (not sooner than 2000 , probably much later), the importance of agricultural exports in the Israeli export basket would be even smaller than currently, and Israel would anyway have ample time to adjust to the new situation. Turkey would have as well to adjust to EC-92 related directives. This may have some favorable impact on the tourism sector of Israel (see below).

\section{TRADE CREATION}

Israel's exports to and imports from Turkey in 1990 were respectively $\$ 88.2$ million and $\$ 26.2$ million. The present commodity composition of mutual trade is given in Table 3.

For Israel, Turkey's membership in the EC would imply the addition of a market (until now very closed) with a GNP roughly equivalent to that of Portugal and Greece together (about 5\% of the EC-12 GNP), to which she will be able to export at privileged prices (because of the Israel-EC FT). Turkey is much closer than any of these two countries or Spain, all three with which Turkey can be compared in many ways. Distance is a factor facilitating servicing and replacement of spare parts and potentially even more important, intra-industry trade (e.g. trade in components). Bulk products can also enter international trade more easily (e.g. cement, building materials) as well as highly perishable goods (such as fresh fish). There is much room for optimism for industrial exports which will get duty and quota-free access into the Turkish market; not so for agricultural products, since the CAP will apply (e.g. reference prices), although for most products Turkish imports will also be duty free, as a result of application by EC of new rules on agricultural trade contained in the additional protocol signed between Israel and the EC upon Spain's and Portugal's accession into the Community. Although GDP per capita is less than a third the one of any OECD country (but for Portugal), the picture changes somewhat if GDP per capita is calculated on a PPP basis, in which case it appears that real income per capita is more than half 
the one in Greece and Portugal ${ }^{12}$. Moreover, Turkey's GDP growth has been the highest in the OECD in the 1980s and this trend could well continue. Membership in the EC could itself stimulate growth in Turkey as it did for Spain and Portugal. The EC will be obliged as well to give a helping hand to Turkey in order to facilitate restructuring where needed. On the other hand, population-wise Turkey is much larger than any of these two countries. In fact the population of Turkey is almost equal to the one of Spain, Portugal and Greece together ${ }^{13}$. Demographic data are particularly relevant for the Israeli exporter of mass comsumption products (including food). In table 1 it is clear that Israeli exports to Turkey are abnormally low nowadays not because of Turkey's GNP per capita, but because tariffs and NTBs on Israeli exports are high while there are pretty inexistant on Israeli exports to Greece, which is about the same distance than Turkey from Israel and has a GNP which is two thirds the one of Turkey ${ }^{14}$. Using Greece as a yardstick, we could expect annual exports to Turkey to be after it acceeds into the EC four to five times as large as they were in 1987. Italy is further away from Israel than Turkey and in spite of it, the ratio of Israeli exports to the importer's GNP is about the same, which points again to the existence of a trade potential. 1987 data are not the appropriate benchmark for Spain and Portugal, since they entered only in $\mathbf{1 9 8 6}$ to the EC and duty free access for Israeli products to both newcomers is only scheduled for 1993 . Using 1990 data we would find already a tremendous expansion of Israeli exports to Spain and Portugal. Roughly speaking, exports to Turkey could expand by 80 to 100 million \$ if free trade was applied by Turkey.

12 See OECD Economic Surveys: Turkey 1990-1991, Paris, OECD, 1991 where the Turkish GDP per capita on a PPP basis is for 1988 \$ 4348, while the one of Portugal and Greece are $\$ 6737$ and \$ 6786 respectively. Even more striking is the fact that Turkey's GDP calculated on a PPP basis is two thirds the one of Spain and almost four times the one of Gereece.

13 In 1989, almost 55 million, while the other three countries together 59 million. Note as well that the three countries' populations tend to stagnate, which is not the case for Turkey. By 2000 Turkey's population will reach the 72 million mark.

14 Trade between Israel and Turkey may also be low because both countries give tariff preferences to the EC which they do not apply to their mutual trade. This affects Turkey nowadays much more than Israel, since Israel has been giving duty-free access to EC exports since 1989. On top of it, Israel is dismantling its tariff progressively vis-a-vis the US. 
TABLE 1: ISRAEL'S EXPORTS TO FIVE MEDITERRANEAN COUNTRIES RANKED ACCORDING TO THEIR G.N.P., 1987

$\begin{array}{lcccc}\text { DESTINATION } & \begin{array}{c}\text { ISRAEL EXPORTS } \\ \text { (million \$) }\end{array} & \begin{array}{c}\text { G.N.P. OF capita } \\ \text { Per }\end{array} & \text { Overall } & \begin{array}{c}\text { POPULATION } \\ \text { (millions) }\end{array} \\ \text { ITALY } & 307166 & 10430 & 598.030 & 57.355 \\ \text { SPAIN } & 99229 & 6010 & 233.261 & 38.832 \\ \text { TURKEY } & 34259 & 1220 & 63.982 & 52.623 \\ \text { GREECE } & 96615 & 4030 & 40.277 & 10.003 \\ \text { PORTUGAL } & 19441 & 2870 & 29.198 & 10.161\end{array}$

SOURCE: World Bank Atlas

UN Commodity Trade Statistics

While it is true that Israel would be competing in the Turkish market on a par with all the 18 members of the European Economic Area as far as tariffs and most NTBs is concerned, it would have clear locational and language advantages in relation to most Western European competitors.

Viewed from Turkey, increasing imports from Israel would be beneficial, in that most would be trade creation rather than trade diversion. First, as indicated above, Israel competes mostly with Westren European countries in the Turkish market. Second, Turkey's average tariff was relatively high.

Israeli exports would expand greatly for different reasons:

First, the MFN tariff applied by Turkey on Israel imports is at present rather high particularly when compared to the rate applied by Israel's main trade partners, namely the US and the EC, which apply zero-rates. Other OECD countries apply very low tariffs. In some cases, Israel benefits from GSP treatment (e. g. in Switzerland). In other words, Israeli exporters look elsewhere than on Turkey.

Second, Israel suffers at present from trade diversion in the Turkish market against her and in favour of EC countries. Since many of Israel's industrial and agricultural exports overlap with those of the one or the other EC member country, particularly those close to Turkey (such as Greece, Italy or Germany), this is particularly damaging nowadays ${ }^{15}$.

15 The trade diversion argument does not seem to play in the other direction since Turkey is not competing by and large with other European countries in the Israeli market nowadays. 
Third, exports are hindered by the lack of diplomatic relations at the highest level and the request of visas for travelling to Turkey. This would presumably change upon Turkey's accession into the EC, although that could happen even before.

Israeli industrial (and even some agricultural) products which Israel exports would be favored almost across the board, given the relative high income and price elasticities in destination countries for these products. The list includes machinery, transport equipment, instruments, pharmaceuticals, electronic and telecommunication equipment, etc. Many of these products are not exported at all to Turkey nowadays, for the reasons mentioned above (see table 3). Israel would have an advantage over some European countries in that many of these products require servicing and follow-up (e.g. scanners), something wihch could be cheaply done from Israel, as compared, say, from Britain. Israel would also tend to displace in the Turkish market some advanced NICs whose exports to the latter would be submitted to the CCT and EC NTBs (such as anti-dumping duties). It is unlikely that Turkey would be obliged by the EC to apply GSP rates to Third World countries exports at least in the foreseeable future.

TABLE 2: TURKEY'S EXPORTS TO FOUR EC COUNTRIES AND ISRAEL, RANKED ACCORDING TO THEIR G.N.P., 1987

\begin{tabular}{lcccc} 
DESTINATION & $\begin{array}{c}\text { EXPORTS } \\
\text { (million \$) }\end{array}$ & \multicolumn{2}{c}{ G.N.P. OF COUNTRY } & POPULATION \\
U.K. & 541407 & 10540 & 599.804 & 56.891 \\
ITALY & 850614 & 10430 & 598.030 & 57.355 \\
SPAIN & 70570 & 6010 & 233.261 & 38.832 \\
GREECE & 58853 & 4030 & 40.277 & 10.003 \\
ISRAEL & 21683 & 7410 & 32.434 & 4.375
\end{tabular}

SOURCE: World Bank Atlas

UN Commodity Trade Statistics

With the help of Table 2 we can speculate that Turkish exports to Israel will expand substantially, particularly in percentage terms. The Israeli market is in 1991 larger than the Greek or Portuguese one ${ }^{16}$. The Israeli economy is roughly $6 \%$ as large as the Italian economy, but Israel absorbs less than $3 \%$ 16 See The World Bank Atlas 1990. 
the amount bought by Italy from Turkey. Upon accession into the EC we could expect that Turkey's exports to Italy would themselves expand, given restrictions applied nowadays by the EC on Turkish food and textile products. Moreover, Israel's growth prospect in coming years seems good, given new trends in immigration. On the other hand, Israel has decided to eliminate progressively NTBs such as quotas on non-preferred imports (including those from Turkey) as from September 1991, therefore reducing any supplementary export expansion potential upon application of the Israel -EC agreement to Turkey-Israel trade. Taking into account all this we could easily expect Turkey to triple their exports to Israel from present levels, expanding by at least 50 million \$ compared to 1987 if free trade was applied by Israel.

Israeli tariffs are particularly low for machinery, mineral products and chemicals but higher than average for other manufacture products such as cotton fabrics, clothing, glass, iron and steel products, white goods. For some of these products both price elasticities and tariff levels tend to be higher than average. These are thus the categories that are likely to be favored most by the new situation. Observe that, for most of them, Turkey has a comparative advantage. Since in many cases there is some kind of Israeli importcompeting production, much would be trade creation, although trade diversion against non-preferred Third World countries in South East Asia or Latin America must also be taken into account. On the other hand, Israeli imports of food, tobacco and mineral products from Turkey would not tend to expand because of low price and income elasticities and because tariffs are nil or very low already now. Clearly Turkish export potential to Israel is in industrial products which she begins to export already to the EC (see table 4) but not yet to Israel (see table 3 ).

One can also envisage semi-manufactured products and components being shifted back-and-forth between Turkey and Israel for further processing with the intention of exporting the product ultimately to the EC or the US market.In other words, we are speaking about intra-industry trade with a view of selling the end product world-wide. Some parts in the production process would be completed in Turkey, while other parts would be completed in Israel. As a general rule, it seems more appropriate that the last processing stage be done in Israel, particularly because then the final product could be sold in the US as an Israeli product and thus benefit from the US-Israel FTA. In other words, the potential for Turkish-Israeli intra-industry trade seems enormous and for related reasons trade in industry-related services as well (e.g. transport, telecommunications, banking, business and professional services, software, tchnology transfer and so on). 
TABLE 3: ISRAEL-TURKEY TRADE BY COMMODITIES, 1987

SITC NAME OF CATEGORY

02 Dairy products, Birds' egg

04 Cereals and preparations

05 Vegetables and fruit

06 Sugar and preparations, Honey

07 Coffee, Tea, Cocoa, Spices

26 Textile fibres and waste

27 Crude fertilizers, minerals nes

29 Crude animal, veg. materials nes

51 Organic chemicals

52 Inorganic chemicals

58 Plastic materials etc.

59 Chemical materials nes

62 Rubber manufactures nes

64 Paper, paperboard and manuf.

65 Textile, yam, fabrics, etc.

66 Nonmetal minerals manuf. nes

67 Iron and steel

69 Lekay manufactures nes

72 Machines for special industries

74 General industiral machinery nes

77 Electric machinery nes etc.

78 Road vehicles

79 Other transport equipment

87 Precision instruments nes

89 Misc. manufactured goods nes
IMPORTS EXPORTS

(Thousand \$) (Thousand \$)

$\begin{array}{rr}- & 132 \\ - & 396 \\ 9273 & - \\ 406 & - \\ 618 & - \\ - & 1602 \\ 1006 & 3897 \\ 1194 & 875 \\ - & 10557 \\ - & 7966 \\ - & 382 \\ 139 & 452 \\ 202 & 288 \\ 252 & 552 \\ 2128 & 432 \\ 297 & 323 \\ - & 764 \\ 786 & 426 \\ 349 & - \\ - & 592 \\ 350 & - \\ 109 & - \\ 168 & 700 \\ - & 105 \\ 707 & 1117\end{array}$

SOURCE: UN Commodity trade statistics 1987 


\section{EXPORT SIMILARITY}

A number of export similarity indexes are mentioned in the economic literature, among which the best known is the Finger-Kreinin index of similarity of export patterns. For two countries ( $a$ and $b$ ) exporting to a third market (c) the formula is as follows:

$$
\mathrm{S}=\sum_{\mathrm{i} \quad \mathrm{min}}(\mathrm{Si}, \mathrm{Si}) \times 100
$$

where $\mathrm{Si}_{\mathrm{ac}}$ and $\mathrm{Si}_{\mathrm{bc}}$ represent the export shares of commodity $\mathrm{i}$ in the exports to $c$ of $a$ and $b$ respectively. For each commodity we select the lower of the two. An index of 100 indicates perfect overlap, while 0 represent no overlap whatsoever. Pomfret (1981) and Donges et al. (1982) have used this index in the past for analysis of similarity among Mediterranean countries' agricultural exports to the EC. The first, using 1977 EC import data at the SITC three-

\begin{tabular}{|c|c|c|c|}
\hline SPAIN & GREECE & PORTUGAL & ALL THREE \\
\hline 51.6 & 43.8 & 8.0 & 45.6 \\
\hline
\end{tabular}
digit level arrived at the following results with respect to Israel:

In order to maintain some parallelism, we have calculated the same index (i.e. only for agricultural products, namely SITC categories $0,1,2,4$ ) using the U.N. Commodity Trade Statistics. Below are the results obtained for 1980 and 1987 (last year for which we found homogenous data at the threedigit level):

$\begin{array}{lll}\text { Agricultural exports } & \text { TURKEY } 1980 & \text { TURKEY } 1987 \\ & 55.3 & \end{array}$

Several interesting conclusions follow:

1.Similarity between Israel and Turkey as far as agricultural exports to the EC goes has been diminishing substantially in the 1980s.

2. The overlap was in the early 1980 s at least as large as the one between Israel and Spain, rated to be on collision course in the EC market at the time of Spain's entry into the EC.

3. The overlap remains high even now, particularly if we compare with results obtained for Greece (not to speak of Portugal) in 1977.

Given the fact that most Turkish and Israeli exports to the EC are indus- 
trial, we have also calculated the overall index as well as the degree of overlap in industrial exports both for 1980 and 1987.

\begin{tabular}{lccc} 
& \multicolumn{1}{c}{ TURKEY 1980 } & & TURKEY 1987 \\
\cline { 2 - 2 } Industrial exports & 28.71 & & 36.77 \\
Total exports & 33.18 & & 40.68
\end{tabular}

Again, several interesting conclusions can be drawn:

1. Similarity of industrial exports to the EC is smaller than in agricultural products.

2. There is however a tendency for industrial exports of both countries to become more similar.

3. In 1987 the index for industrial exports was very close to the one obtained for agricultural exports.

4. With regard to total exports, the similarity of Israeli exports with those of Turkey has increased from 1980 and 1987. This conclusion is the reverse of Tovias' own findings in a previous study regarding Spain and Israel in the $1970 \mathrm{~s}^{17}$, where it was shown that Spanish and Israeli exports to the EC were increasingly dissimilar. The most obvious explanation is that whereas Spain had been shifting away from labour-intensive industries (such as clothing) and towards standardized capital-intensive products (such as cars) while Israel had not, both Turkey and Israel have in the 1980s continued to concentrate on sales of labour-intensive products to the Community, both industrial and agricultural and on top of it both have begun to export machinery to the EC (see section on revealed comparative advantage below).

\section{REVEALED COMPARATIVE ADVANTAGE IN TRADE WITH THE EC}

This section adopts an alternative approach to the issue of Israel's competitiveness in EC markets in relation to that of Turkey. We assess the evolution of Israel's comparative advantage in EC markets in the 1980s and compare the trend with that of Turkey. Moreover we attempt to discover whether the sectoral composition of Israel's comparative advantages coincides with that of Turkey and whether there was a change over time in this respect.

17 See Tovias (1988), p. 177. 
First, we calculated indexes of "revaled comparative advantage" (RCA) by sector (at the SITC two-digit level) for the two countries, using 1988 data published by the OECD. ${ }^{18}$

Second, we calculated rank correlation indexes between Israel's sectoral RCAs and the corresponding RCAs of Turkey. Third, we repeated the same procedure for Israel and Turkey for the year 1983.

There are different indexes of comparative advantage. We used the "relative trade-balance" index -a relative export - to - import ratio of each sector, used originally by the late B.Balassa to identify "revealed comparative advantages" of a given country. A positive trade balance in a given sector is said to represent a comparative advantage of that sector, while a negative trade balance reveals a disadvantage. The balance is then related to total trade which acts as normalizer. Nevertheless the RCA index is only a rough approximation of the "true" comparative advantage. Ideally, the index should be based upon trade figures resulting from a free trade setting and not upon "real world" figures, which are obviously the only ones available. The index is also very sensitive to the level of disaggregation used and to product heterogeinity. Finally, since it is a ratio, it does not distinguish between large and small absolute values of trade.

Bearing all these sohrtcomings in mind, we arrive at the following conclusions on the basis of a quick analysis of Table 4:

1) Israel displays high RCA indexes (larger than 0.4) in trade with the EC for the following categories in 1988, presented in decreasing order of RCA:

\begin{tabular}{|c|c|c|}
\hline SITC & Name & Index \\
\hline 56 & Fertilizers (excl. group 272) & 0.94 \\
\hline 0.5 & Vegetable and fruit & 0.88 \\
\hline 29 & $\begin{array}{l}\text { Crude animal and vegetable materials (incl. } \\
\text { flowers and cotton) }\end{array}$ & 0.88 \\
\hline 28 & Metalliferous ores and metal scrap & 0.83 \\
\hline 72 & Specialized machinery & 0.76 \\
\hline 84 & Articles of apparel and clothing & 0.73 \\
\hline 27 & Crude fertilizers excl. category 56 & 0.69 \\
\hline
\end{tabular}

18 OECD, Foneign Trade by Commodities, Vol. 5, 1988. 
$\begin{array}{lll}01 & \text { Meat and meat preparations } & 0.69 \\ 52 & \text { Inorganic chemicals } & 0.60 \\ 26 & \text { Textile fibres and wastes } & 0.54 \\ 22 & \text { Oil seeds } & 0.51 \\ 71 & \text { Power generating machinery and equipment } & 0.49\end{array}$

SOURCE: Table 4

These indexes can be compared with those which we calculated for 1983 (see below) as well as with those published by Tovias (1988) relating to 1979. What is worthwhile noting is that in 1979 Israel displayed revealed comparative advantage in petroleum and petroleum products and cork and wood manufactures but not in any kind of machinery or chemicals as a decade afterwards.

2) The corresponding list for Turkey is:

\begin{tabular}{|c|c|c|}
\hline SITC & Name & \\
\hline 05 & Vegetable and fruit & 0.99 \\
\hline 85 & Articles of apparel and clothing & 0.98 \\
\hline 72 & Specialized machinery & 0.96 \\
\hline 33 & Petroleum and petroleum products & 0.96 \\
\hline 41 & Animal oils and fats & 0.90 \\
\hline 83 & Travel goods & 0.90 \\
\hline 27 & Crude fertilizers (excl. category 056) & 0.87 \\
\hline 12 & Tobacco and tobacco manufactures & 0.8 \\
\hline 22 & Oil seeds & 0.82 \\
\hline 03 & Fish, crustaceans and preparations & 0.76 \\
\hline 51 & Organic chemicals & 0.72 \\
\hline 06 & Sugar, sugar preparations and honey & 0.72 \\
\hline 65 & Textile yarn and fabrics & 0.69 \\
\hline 34 & Natural gas and manufactures thereoff & 0.51 \\
\hline
\end{tabular}

SOURCE: Table 4

The following categories overlap with the ones of Israel:

Vegetable and fruit, articles of apparel and clothing, specialized machinery, 
crude fertilizers and oil seeds.

We have calculated the Spearman rank correlation index of RCA index series of Turkey and Israel for 1988. Perfect correlation means an index of 1, while no correlation implies an index of 0 .

Spearman rank correlation index for $1988=0.459$.

For comparison purpose, it is worthwhile noting that this index is lower than the one found by Tovias (1988) using 1979 data for the couples IsraelSpain (0.687) and Israel-Greece (0.559), but higher than the one relating to the couple Israel-Portugal (0.352).

Turning now to 1983 (see table 5), the following goods were not among the 1988 categories on the Israeli list, reflecting new Israeli comparative advantage developed during the 1970s:

Specialized machinery, meat and meat preparations, oil seeds, powergenerating machinery and equipment.

On the other hand, the list did include the following categories which did not appear subsequently in 1988:

Miscellaneous edible goods and preparations and petroleum products.

Clearly Israel has been shifting comparative advantage in the direction of machinery and equipment.

The following products are not included in the 1983 list for Turkey: Specialized machinery, animal oils and fats and organic chemicals.On the other hand there are many categories which appeared in the 1983 RCA list of Turkey which did not reappear in the list of 1988: Meat and meat preparations, coffee, tea and spices, feedstuff for animals (excluding unmilled cereals), miscellaneous edible preparations, textile fibers and wastes, cork and wood, crude animal and vegetable materials, cereals and cereals preparations. Observe that these are all agricultural products and raw materials.

All this points to the important fact that Turkey's performance in EC markets in the 1980s increased for industrial products, such as machinery and chemicals, but decreased for agricultural products. In the case of Israel, the performance increased for machinery and meat preparations, while it was roughly maintained in agriculture. Observe that there is new overlap of comparative advantage between Israel and Turkey in specialized machinery, but diminished overlap in miscellaneous edible products, meat and meat preparations, textile fibers and wastes and crude animal and vegetable materials. 
The 1983 Spearman rank correlation index of RCA between Israel and Turkey reached 0.338 , which is much lower than the one obtained for 1988 . Accordingly it appears that the level of similarity between Turkey and Israel's comparative advantages in EC markets increased over the 1980s, confirming what was found previously for export similarity. We have confirmed as well that overlap in agricultural exports is diminishing progressively, not so much because the two countries have diversified their exports is diminishing progressively, not so much because the two countries have diversified their exports, but for the fact that Turkey seems to have lost competitiveness in this area.

Table 4: REVEALED COMPARATIVE ADVANTAGE OF ISRAEL AND TURKEY IN TRADE WITH THE EC, 1988

\begin{tabular}{llrrr}
\cline { 1 - 1 } SITC & & Name of category & Israel & Turkey \\
\cline { 4 - 5 } & & Live animals other than division 03 & -0.604 & -0.936 \\
01 & & Meat and meat preparations & 0.690 & 0.095 \\
02 & & Dairy products and birds' eggs & -0.422 & -0.743 \\
03 & & Fish, crustaceans and prep. thereof & -0.544 & 0.764 \\
04 & & Cereals and cereal preparations & -0.861 & -0.183 \\
05 & & Vegetable and fruit & 0.880 & 0.991 \\
06 & Sugar, sugar preparations and honey & -0.919 & 0.716 \\
07 & Coffee, tea, cocoa, spices and manuf. & -0.691 & 0.187 \\
08 & Freedstuff for animals (excluding & -0.606 & -0.075 \\
& unmilled cereals) & & \\
09 & Misc. edible and preparations & 0.120 & -0.302 \\
11 & Beverages & -0.784 & -0.576 \\
12 & Tobacco and tobacco manufactures & -0.907 & -0.838 \\
21 & Hides, skins and furskins, raw & -0.870 & -0.944 \\
22 & Oil seeds and oleaginous fruit & 0.507 & 0.815 \\
23 & Crude rubber & -0.939 & -0.910 \\
24 & Cork and wood & -0.950 & -0.834 \\
25 & Pulp and waste paper & -0.946 & -0.998 \\
26 & Textile fibres and their wastes & 0.544 & 0.268 \\
27 & Crude fertilizers other than div. 56 & 0.694 & 0.866
\end{tabular}


and crude minerals

Metalliferous ores and metal scrap

$\begin{array}{ll}0.833 & -0.219\end{array}$

Crude animal and veg. materials n.e.s.

$0.879 \quad 0.388$

Coal, coke and briquettes

$-0.795 \quad-0.995$

Petroleum, petr. products and related

$-0.998 \quad 0.918$ materials

Gas, natural and manufactured

$\begin{array}{ll}-0.998 & 0.507\end{array}$

Electric current

Animal oils and fats

Fixed veg. oils and fats, crude

$0 \quad 0$

$\begin{array}{ll}-0.121 & 0.898\end{array}$

$-0.835-0.966$

refined or fractinoted

Processed animal and veg. oils and fats

$-0.988$

$-0.939$

Organic chemicals

0.060

0.717

Inorganic chemicals

0.602

$-0.513$

Dyeing, tanning and colouring materials

$-0.948$

$-0.965$

Medicinal and pharmac, products

$-0.739 \quad-0.810$

Essential oils and pharmac, products

$-0.744 \quad 0.680$

Fertilizers other than group 272

0.936

0.164

Plastics in primary forms

$-0.421 \quad-0.752$

Plastics in non-primary forms

0.195

$-0.862$

Chemical materials and prod. n.e.s.

$-0.454 \quad-0.977$

Leather, leather manufacture and dressed

$-0.778$

$-0.885$ furskins

62

Rubber manufactures n.e.s.

$0.021 \quad 0.149$

Cork and wood manufactures

0.098

$-0.415$

(exc. furniture)

64

Paper and paper manufactures

$-0.62$

$-0.971$

Textile yarn, fabrics and related products

$-0.161$

0.692

Non-metallic mineral manufactures

0.436

0.046

n.e.s.

67

Iron and steel

$-0.941-0.586$

68

$-0.756 \quad-0.527$ 


\section{9}

71

72

73

74

75

76

77

78

79

81

82

83

84

85

87

88

89
Manufactures of metal n.e.s.

Power generating machinery and equipment

Specialized machinery

Metal-working machinery

Other industiral machinery and parts

Office machines and ADP equip.

Telecommunication and sound recording apparatus $\begin{array}{ll}-0.372 & -0.530\end{array}$

$0.494-0.855$

$0.763 \quad 0.965$

$-0.475 \quad-0.908$

$\begin{array}{ll}-0.613 & -0.919\end{array}$

$-0.060-0.948$

$0.573-0.565$

$-0.193 \quad-0.808$

$-0.966-0.835$

$-0.045 \quad-0.952$

$-0.943 \quad-0.142$

$0.435 \quad-0.425$

$-0.279 \quad 0.896$

$0.733 \quad 0.981$

Articles of apparel and clothing accessories

Footwear

$\begin{array}{ll}-0.505 & -0.030\end{array}$

$0.002-0.810$

instruments n.e.s.

Photo apparaus, optical

$\begin{array}{ll}-0.653 & -0.980\end{array}$

Misc. manuf. articles n.e.s.

$\begin{array}{ll}-0.257 & -0.509\end{array}$

SOURCE: OECD FOREIGN TRADE BY COMMODITIES 1988 VOL. 5 PARIS, 1991

Table 5: REVEALED COMPARATIVE IDVANTAGE OF ISRAEL AND TURKEY IN TRADE WITH THE EC, 1983

$\frac{\text { SITC }}{00} \quad \frac{\text { Name of category }}{\text { Live animals other than division } 03}$ $\frac{\text { Israel }}{-0.626} \frac{\text { Turkey }}{-0.721}$ 


$\begin{array}{llrr}01 & \text { Meat and meat preparations } & 0.267 & 0.705 \\ 02 & \text { Dairy products and birds' eggs } & -0.989 & -0.417 \\ 03 & \text { Fish, crustaceans and prep. thereof } & -0.807 & 0.992 \\ 04 & \text { Cereals and cereal preparations } & -0.402 & 0.408 \\ 05 & \text { Vegetable and fruit } & 0.928 & 0.989 \\ 06 & \text { Sugar, sugar preparations and honey } & -0.953 & 0.484 \\ 07 & \text { Coffee, tea, cocoa, spices and manuf. } & -0.717 & 0.815 \\ 08 & \text { Feedstuff for animals (excluding } & -0.643 & 0.724 \\ & \text { unmilled cereals) } & & \\ 09 & \text { Misc. edible and preparations } & 0.688 & 0.843 \\ 11 & \text { Beverages } & -0.926 & -0.598 \\ 12 & \text { Tobacco and tobacco manufactures } & -0.995 & 0.937 \\ 21 & \text { Hides, skins and furskins, raw } & -0.523 & -0.953 \\ 22 & \text { Oil seeds and oleaginous fruit } & -0.993 & 0.997 \\ 23 & \text { Crude rubber } & -0.989 & -1.000 \\ 24 & \text { Cork and wood } & -0.902 & 0.504 \\ 25 & \text { Pulp and waste paper } & -1.000 & -0.344 \\ 26 & \text { Textile fibres and teir wastes } & 0.835 & 0.522 \\ 27 & \text { Crude fertilizers other than div. 56 } & 0.762 & 0.905 \\ & \text { and crude minerals } & & \\ 28 & \text { Metalliferous ores and metal scrap } & 0.782 & 0.087 \\ 29 & \text { Crude animal and veg. materials n.e.s } & 0.911 & 0.850 \\ 32 & \text { Coal, coke and briquettes } & -1.000 & -0.999 \\ 33 & \text { Petroleum, petr. products and related } & 0.765 & 0.836 \\ & \text { materials } & -0.196 & 0.677 \\ 34 & \text { Gas natural and manufactured } & 0 & 0 \\ 35 & \text { Electric current } & 0.143 & 0.220 \\ 41 & \text { Animal oils and fats } & -0.967 & -0.332 \\ 42 & \text { Fixed veg. oils and fats, crude } & & \\ & \text { refined or fractionated } & -1.000 & -0.993 \\ 43 & \text { Processed animal and veg. oils and fats } & -0.964\end{array}$




\begin{tabular}{|c|c|c|c|}
\hline 52 & Inorganic $\mathrm{C}$ hemicals & 0.530 & -0.810 \\
\hline 53 & Dyeing tanning and colouring materials & -0.957 & -0.984 \\
\hline 54 & Medicinal and pharmac. products & -0.941 & -0.900 \\
\hline 55 & Essential oils and perfume mater. & -0.815 & -0.501 \\
\hline 56 & Fertilizers other than group 272 & 0.872 & -0.999 \\
\hline 57 & Plastics in primary forms & -0.464 & -0.905 \\
\hline 58 & Plastics in non-primary forms & -0.156 & -0.870 \\
\hline 59 & Chemical materials and prod. n.e.s. & -0.592 & -0.988 \\
\hline 61 & $\begin{array}{l}\text { Leather, leather manufactures and } \\
\text { dressed furskins }\end{array}$ & -0.638 & 0.554 \\
\hline 62 & Rubber manufactures n.e.s. & 0.193 & -0.396 \\
\hline 63 & $\begin{array}{l}\text { Cork and wood manufactures } \\
\text { (exc. furniture) }\end{array}$ & -0.220 & -0.022 \\
\hline 64 & Paper and paper manufactures & -0.848 & -0.861 \\
\hline 65 & $\begin{array}{l}\text { Textile yam, fabrics and } \\
\text { related products }\end{array}$ & -0.238 & 0.761 \\
\hline 66 & $\begin{array}{l}\text { Non-metallic mineral } \\
\text { manufactures n.e.s. }\end{array}$ & -0.206 & -0.157 \\
\hline 67 & Iron and steel & -0.990 & -0.860 \\
\hline 68 & Non-ferrous metals & -0.806 & -0.982 \\
\hline 69 & Manufactures of metal n.e.s. & -0.669 & -0.809 \\
\hline 71 & $\begin{array}{l}\text { Power generating machinery } \\
\text { and equipment }\end{array}$ & -0.524 & -0.810 \\
\hline 72 & Specialized machinery & -0.938 & -0.988 \\
\hline 73 & Metal-working machinery & -0.850 & -0.989 \\
\hline 74 & $\begin{array}{l}\text { Other industrial machinery } \\
\text { and parts }\end{array}$ & -0.816 & -0.964 \\
\hline 75 & Office machines and ADP equip. & -0.422 & -0.955 \\
\hline 76 & $\begin{array}{l}\text { Telecommunication and sound } \\
\text { recording apparatus }\end{array}$ & -0.627 & -0.973 \\
\hline 77 & $\begin{array}{l}\text { Electrical machinery, apparatus } \\
\text { and appliances, n.e.s. }\end{array}$ & -0.663 & -0.960 \\
\hline
\end{tabular}




$\begin{array}{llrl}78 & \text { Road vehicles } & -0.985 & 0.965 \\ 79 & \text { Other transport equipment } & -0.512 & -0.846 \\ 81 & \text { Prefabricated buildings, sanitary } & -0.963 & 0.045 \\ & \text { heating and lighting fixtures n.d.a. } & & \\ 82 & \text { Furniture and parts thereof } & -0.759 & -0.445 \\ 83 & \text { Travel goods, handbags, etc. } & -0.084 & 0.883 \\ 84 & \text { Articles of apparel and clothings } & 0.760 & 0.977 \\ & \text { accessories } & & \\ 85 & \text { Footwear } & -0.716 & 0.110 \\ 87 & \text { Professional and scientific } & -0.088 & -0.957 \\ & \text { instruments n.e.s. } & & \\ 88 & \text { Photo apparatus, optical } & -0.777 & -0.955 \\ & \text { goods, watches and clocks } & & \\ 89 & \text { Misc. manuf. articles n.e.s. } & -0.333 & -0.693\end{array}$

SOURCE: OECD FOREIGN TRADE BY COMMODITIES 1988 VOL. 5 PARIS, 1991

\section{Trade Diversion}

All what has been said on export similarity and RCA indexes can help us to say something about the potential of trade diversion in favour of Turkey and against Israel once she becomes an EC member. It appears that the fear that it would take place for some agricultural products is unjustified. To begin with, Turkey and Israel do not export by and large the same vegetable and fruits to the EC. Turkey is very strong in dried fruit and tobacco, Israel in fresh fruit and vegetables. There is some overlap for grapes and tomatoes. But by the time Turkey would benefit from the protection and support of the CAP (i.e. not sooner than in a decade), those products will be even less important than now in the Israeli export basket to the EC. As far as industrial products are concerned, the overlap in machinery should be of no concern for Israel, since both countries have already duty-and quota-free access into the EC. Much more problematic would be the case of clothing, given the fact that, while Israeli exports to the EC enter unhampered by any restrictions into the EC, this is certainly not the case for Turkey. Rivalry between the two countries could even increase from now to time of accession. Turkey is after 
all like Israel close to the European fashion centers, an advantage that both countries share when compared to South Eastern Asia or Latin America.

\section{REVERSE TRADE DIVERSION}

Tourism flow diversion in favour of Israel may be anticipated as a result of EC enlargement to Turkey (as well as Cyprus and Malta) for the following reasons:

- There will be a rise in the new entrants' food prices (a real perverse effect) as a result of adoption of the CAP.

- There will be an increased tendency for wage to come closer to the EC average, once the freedom of movement of workers, capital and goods is established.

As for Spain and Italy, Turkey (as well as Malta and Cyprus) will become a more expensive country for tourism once in the EC. This will favour destinations further afield, such as Israel.

\section{CONCLUSIONS}

We have shown in this paper that it is in Israel's interest that Turkey be a member of the European Community for the following reasons:

a) Economically, trade in goods and in ancillary services between Turkey and Israel will expand, as a result of adoption by Turkey of the Israel-EC FTA agreement. This includes a large potential in so-called intra-industry trade. This in itself could lead to joint ventures with a view to exporting to the EC, EFTA and last but not least the US.

b) Politically, the EC will be more interested than ever in a stable and prosperous Middle East. As a member of the EC Turkish-Israeli relations will be conducted at the highest level.

c) The cheap-labor advantage in Turkish exports to the EC will not play the same role as now as a result of free trade in goods and free factor movements between Turkey and the EC. The Community will be a relatively expensive destination for tourists, which will in turn be attracted by locations outside the EC such as Israel. 
However, the already meager EC's financial cooperation with Israel will tend to be scaled down and Israel can also expect trade diversion against her and in favour of Turkey in textiles and clothing. In fact, there is nothing to complain about that, since this will be the result of preference erosion. The country which is nowadays being discriminated openly by the EC is Turkey, something which indirectly benefits Israel.

From a policy viewpoint, it would be advisable for the government of Turkey and Israel to begin negotiations right now with the aim to bringing down tariffs on their mutual trade in paralell as they are doing or planning to do with both the EC and EFTA. This would avoid transitional trade distortions until 1996, when the situation will tend to normalize itself, as a result of Turkey's adoption of the Israel-EC FTA.

\section{BIBLIOGRAPHY:}

\section{Books and articles}

Aktan O. (1985), The Second Enlargement of the European Communities. Probable Effects on the Members and the New Entrants, European Economic Review, Nr. 28, pp. 279-308.

Baysan, T. (1984), Some Economic Aspects of Turkey's Accession to the EC: Resource Shifts, Comparative Advantage, and Static Gains, Journal of Common Market Studies, Vol., 23, No. 1, September, pp. 15-34.

Ben-Shahar H., Fishelson G., Hirsch Z., eds. (1989), Economic Cooperation and Middle East Peace, London, Weidenfeld and Nicolson, 1989.

Burrows, B. (1978), A Community of Thirteen? The Question of Turkish Membership of the EC, Journal of Common Market Studies, Vol., 17, No. 2, December, pp. 143-50.

Donges, J. et al. (1982), The Second Enlargement of the European Community, Tubingen, J.C.B. Mohr (Paul Siebeck).

Gruen, G.E. (1985), Turkey's Relations with Israel and its Arab Neighbours: The Impact of Basic Interests and Changing Circumstances, Middle East Review, Vol. 17, No. 3, pp. 33-43.

Kramer, H. (1988), Westeuropa und die Turkei: auf dem Weg zum 13. 
Mitglied der EG?, Ebenhausen, Stiftung Wissenschaft und Politik.

Landau, J. (1980), Politics, Economics and Religion: Turkey and the European Common Market, Oriente Moderno, Nr. 1-6, pp. 163-71.

Pomfret, R. (1981), The Impact of EEC Enlargement on Non-Member Mediterranean Countries' Exports to the EC, Economic Journal, Vo. 91, September, pp. 726-9.

Rustow D. and Penrose, T. (1981), Turkey and the European Community, The Mediterranean Challenge IV, Brighton, Sussex European Research Center.

Tovias, A. (1988), The Impact of the Second Enlargement of the EC upon Israel's Balance of Payments, in Grielsammer, I. and Weiler, J. (ed.), Europe and Israel: Troubled Neighbours, Berlin, Walter de Gruyter (for the European University Institute, Series C: Political and Social Sciences. 9), pp. 17394.

Tovias, A.(1988), "The Impact of the Southern Enlargement of the European Community on Its System of Foreign Relations", The Jerusalem Journal of International Relations, Vol. 10, No. 3, September, pp. 11-32.

Tovias, A. (1988), "Les effets exterieurs des politiques domestiques communautaires sur les pays non members: le cas des pays mediterraneens", Journal of European Integration, Vol. 12, No. 1, pp. 51-70.

Tovias, A. (1992), "The Contribution of the EC to Peace and Economic Prosperity in the Mediterranean and the Middle East", Jerusalem Journal of International Relations, Vol. 14, No. 1, March

Turkey in Europe - An Assessment of Turkey's Application to Join the EC. (1990) An Intelligence Digest Special Briefing Paper No. 133 U.K.

Vaner, S. (1982), La Turquie, la Communaute europeenne elargie et la Mediterranee, in J. Touscoz et autres: La Communaute Economique Elargie et la Mediterranee, Quelle Cooperation? Paris, PUF, pp. 64-94.

Yannopoulos G.N. ed. (1989), European Integration and the Iberian Economies, London, Macmillan.

Turkish Industrialists and Busienssmen's Association (1988), The Turkish Economy.

Deutsches Orient Institute (1984), Turkey and the European Community- 
Summary Report, December.

OECD Economic Surveys - Turkey, various years.

Overseas Business Report (1989), Marketing in Turkey, April.

"Ready for Europe? A Survey of Turkey," The Economist, vol. 307, No. 7555, June 181988.

Newspapers and news agencies

Globes (Israel) December 22 1990, February 26 1991, March 1 1991, March 7 1991, March 29 1991, April 1 1991, July 151991.

Haaretz, April 28 1991, October 18 1991, October 281991.

EUROPE February 8 1990, June 6 1990, June 7 1990, July 30-31 1990 October 24 1990, January 25 1991, March 2 1991, March 61991.

TELEX MEDITERRANEE No. 333, February 121991

\section{Official Publications}

Bulletin of the European Communities:

$4,1987,3-1988,9-1988$,

6- 1989, 7/8-1989, 9-1989, 11-1989, 12-1989, 1/2 1990,

3- 1990, 6-1990, 7-1990, 3-1991, 5-1991.

Commission Communication on Strengthening Relations with Turkey/ Information 39/90 June 61990.

Commission's Opinion on Turkey's Request for Accession to the Community, Europe Documents, Europe, December 201989.

Agreement Estblishing an Association Between the EEC and Turkey/ Official Journal of the European Communities L 217, December 29 1963.

The Additional Protocol and Financial Protocol, Official Journal of the European Communities L 293, December 291972.

\section{Interviews}

Interview with Irit Lilian, First Secretary in the Middle East Division of the Israeli Foreign Ministry, January 1991. 